\title{
A RESPONSABILIDADE DE SER LEITOR
}

Inicio este Editorial em companhia de Paulo Freire (petulância, né?!), mas é que ontem acabei de re-ler (agora com maior maturidade) o livro Pedagogia da Autonomia e com este texto relembro que ser professor exige segurança, competência, generosidade, comprometimento, desejo de intervenção, liberdade, autoridade, saber escutar, saber dialogar, gostar de gente etc. Ser professor é uma grande responsabilidade!

Ler também é um ato de muita responsabilidade. Conseqüentemente, os textos que criamos cotidianamente são de muita responsabilidade. Falo de textos corporais, verbais e escritos, como este eletronicamente escrito.

Sempre defendi que escrever, além de ser um exercício de organização de idéias, é um risco, pois corremos o risco de fazerem uma leitura equivocada do que escrevemos. Mas se escrever exige uma dose de coragem, ler exige muito mais.
Ler é promover o encontro de textos existentes dentro de nós com os produzidos por outrem; e que podem, muitas vezes, causar uma sensação deliciosamente desafiante.

Esta é a proposta dos artigos contidos nesse número da Revista Informação\&Informação. Em um deles Maria Inês Tomaél, pesquisando redes de informação brasileiras, identifica cinco gêneros delas, ou seja, rede de informação especializada, rede compatibilização da informação, rede de serviços de informação, rede de processamento de informação e rede de informação digital (o que sabemos a respeito delas?).

Em outro, encontramos a "voz" da arquiteta Denise Morado Nascimento, que, de mão dadas com Peter Berger, Thomas Luckmann e Pierre Bourdieu discute a informação como prática social (que bom ouvir vozes de outras áreas!). 
Em seguida, preocupadas com a relação usuário de biblioteca e bibliotecário, mais especificamente no Setor de Referência, Rosane S. Alvares Lunardelli e Solange Palhano de Queiroz, no artigo intitulado A proxemia e o fazer do bibliotecário provocam uma reflexão a respeito da teoria proxêmica formulada por Hall. Nele as autoras alertam que a distribuição espacial pode propiciar prazer ou desprazer de permanecer em uma unidade de informação (será que estamos atentos para isso?!).

$\mathrm{Na}$ seção de Comunicações temos dois artigos, o primeiro, de autoria de Ana Esmeralda Carelli, Maria Julia Giannasi e Vilma Aparecida Gimenes da Cruz aborda a produção sobre EAD no Open Learning: the Journal of Open and Distance Learning, e o segundo, escrito pelas bibliotecárias Ângela Maria de Oliveira, Ivani da Silva e Eunice Silva de Novais, apresentam o resultado de uma investigação realizada com pesquisadores da Universidade Estadual de Ponta Grossa quanto aos canais de informação utilizados por eles em suas pesquisas.

\section{Parabéns para a Revista Informa-} ção\&Informação que além de estar na Rede, está completando 10 anos. Enfim, com este número novos textos estão no ar, e a você, leitor, cabe a responsabilidade de um encontro (de preferência amoroso) com eles.

Carpem Diem e Boa Leitura!

Sueli Bortolin Editora Assistente 